\title{
Flexural and Shear Strengthening of RC Beams with Large Openings by Steel or CFRP Plates
}

\author{
Mohamed A. Kandil $^{1} \quad$ Gaylan. M. Saad $^{2} \quad$ Nageh N. MELEKA ${ }^{3 *}$ \\ ${ }^{1}$ Lecturer, Faculty of Engineering, Menoufia University, Egypt. \\ ${ }^{2}$ MSc. Student, Faculty of Engineering, Menoufia University, Egypt. \\ ${ }^{3}$ Professor, Faculty of Engineering, Menoufia University, Egypt.
}

\begin{abstract}
Existence of transverse openings in the web of reinforced concrete beams is usually used to provide paths for required ducts and pipes which are necessary to accommodate essential services like water supply, sewage, airconditioning, telephone and electricity. However providing an opening in the beam reduces its stiffness, which decreases the overall strength. The provision of openings through the beam depth, changes its simple mode of behavior to a more complex one depending on the size, shape and location of openings. Repair and strengthening of an existing structure may be essential in many cases such as increasing the stiffness of the beams due to making transverse openings in the web of beams after construction. An experimental test program of fourteen RC beams with large openings were strengthened by using additional layers of externally bonded steel plates or CFRP Plates with different techniques then tested by four-point bending test. The behaviors of the tested specimens were investigated with and without strengthening and compared to identify the effectiveness of each method and material of strengthening to increase the flexural and shear strength of beam with different opening location. The research shows that strengthening using CFRP Plates were more effective than using steel plates.
\end{abstract}

Keywords: RC Beams, Large Openings, Strengthening, Steel plates, CFRP Plates.

\section{Introduction}

Creating an opening in the web of the RC beam may be required to provide a track for ducts or pipes. However, making an opening in the web of the beam reduces the stiffness subsequently decreases the resistance for shear, flexure and torsion [1,2]. Therefore, providing a transverse opening in a beam, changes its simple mode of behavior to complex mode depending on the location and the dimensions of the opening [3]. In case of large openings when the depth of the opening $>30 \%$ the total depth of the beam [4], the design of these beams requires special treatment, which falls beyond the range of the major building codes [5,6,7].

Retrofitting or strengthening of beams with openings may be required when loads are expected to be amplified than the design loads due to the usage change of the RC building. Openings may be required also to be created on the web of the beams after finishing the construction. In this case, it is important to compensate for the reduction of the stiffness by a suitable method to retrofit the beam with its full capacity [8,9]. Many researches concentrate on the shear, bending or torsional stresses of beams without openings $[10,11,12]$. Upgrading the stiffness of RC beams of rectangular, $\mathrm{L}$ or $\mathrm{T}$ sections using FRP due to different stresses is investigated by many researches $[13,14]$.

In this research, an experimental test program is arranged to study the behavior of RC beams with central or side web openings subjected to four-point bending test to investigate and compare some different techniques of strengthening to increase the overall stiffness of the beams.

Carbon and glass fiber reinforced polymers (FRP) in the form of rods, plates and wraps woven in one or multi-directions are commonly used for repair and strengthening RC slabs, shells, beams or columns $[15,16,17]$. This may be attributed to the simple installation and the attractive characteristic such that lightweight, high tensile strength, and resistance to corrosion. These advantages have made FRP an attractive choice instead of traditional repair or strengthening techniques. In this research, the strengthening of RC beams with openings was executed by using both steel plates as traditional material or CFRP as an advanced material for comparison. 


\section{Research Objectives}

It is necessary sometimes to make a hole as a transverse opening in the web of the reinforced concrete beam. Providing an opening in the beam decreases the stiffness, which reduces the overall strength of the beam. Limited researches investigate the behavior of beams with openings subjected to shear and flexural stresses. Only very limited literatures are available regarding retrofitting beams with web openings to increase their flexural and shear stiffness. The main object of this research is to determine the efficiency of using different methods and materials as external bonded steel plates and CFRP Plates to increase the strength of rectangular reinforced concrete beams with different large opening locations.

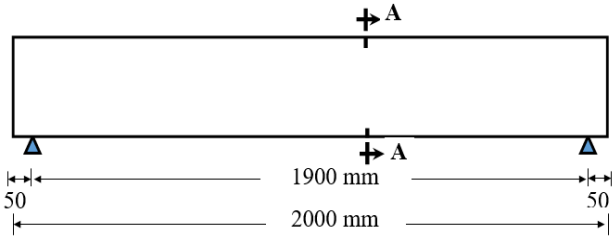

(a) Concrete dimensions

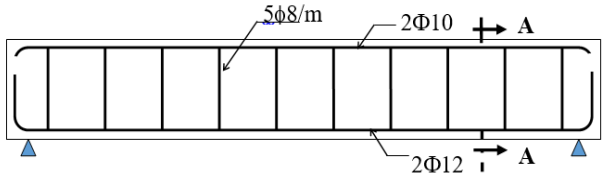

(b) Details of reinforcement

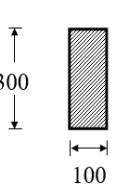

Sec. A -A

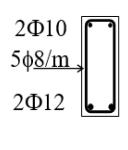

Fig. 1: Dimensions and reinforcment details of control specimen $\mathrm{CB}$

\section{Experimental Program}

Fourteen typical dimensions and reinforcement of the tested RC specimens were cast. The cross-section of the tested beams is $100 \times 300 \mathrm{~mm}$. The span length is $1900 \mathrm{~mm}$. No reinforcement around the openings is considered in this research to simulate making an opening after construction. Three specimens were considered as control beams without any strengthening and classified in Group 1. One of them has no opening; $\mathrm{CB}$, and the other two reference specimens CBSO and CBMO have an opening dimension; $300 \times 100 \mathrm{~mm}$ near one support and at the midspan of the beam respectively. Figures 1,2 and 3 show the concrete dimensions and reinforcement details of control specimens in Group 1; CB, CBSO and CBMO.

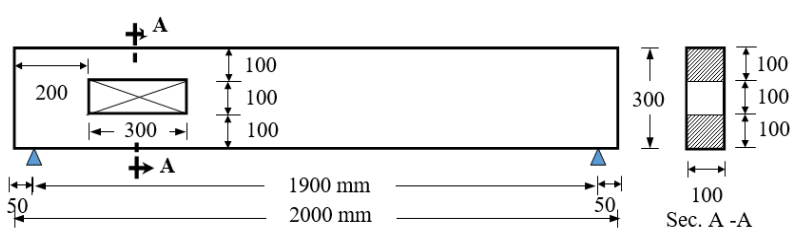

(a) Concrete dimensions
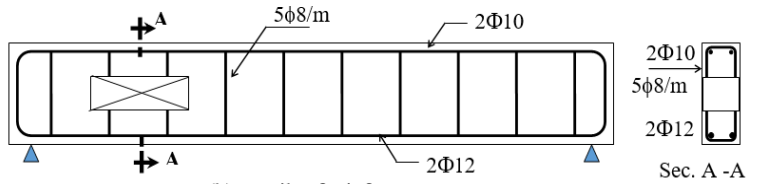

(b) Details of reinforcement

Fig. 2: Dimensions and reinforcment details of control specimen CBSO

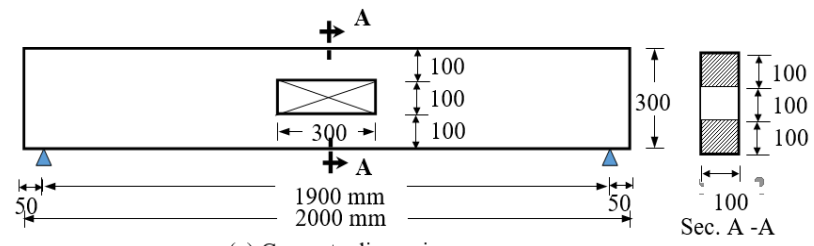

(a) Concrete dimensions

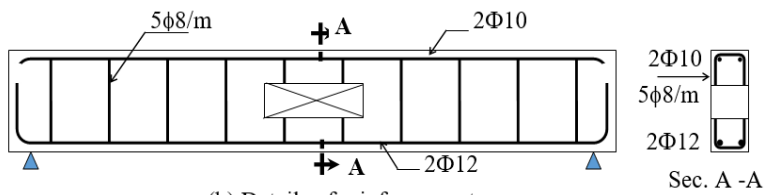

(b) Details of reinforcement

Sec. A -A

Fig. 3: Dimensions and reinforcment details of control specimen CBMO

Five specimens were cast similar to reference beam CBSO with side opening. Three of them were strengthened using steel plates, $2 \mathrm{~mm}$ thick and 100 $\mathrm{mm}$ width and fixed by epoxy Sikadur®-31CF and also with steel dowels $(5 \mathrm{~mm}$ diameter and $30 \mathrm{~mm}$ long) with different techniques. The other two specimens were strengthened using carbon fiber reinforced polymer CFRP Plates of $1.2 \mathrm{~mm}$ thickness and $100 \mathrm{~mm}$ width, Sika Carbodur $\circledast S 1012$, fixed by epoxy Sikadur®-30LP. Figure 4 shows the dimensions of the strengthening for specimens in Group 2; BSOST1, BSOST2, BSOST3, BSOC1 and BSOC2. 


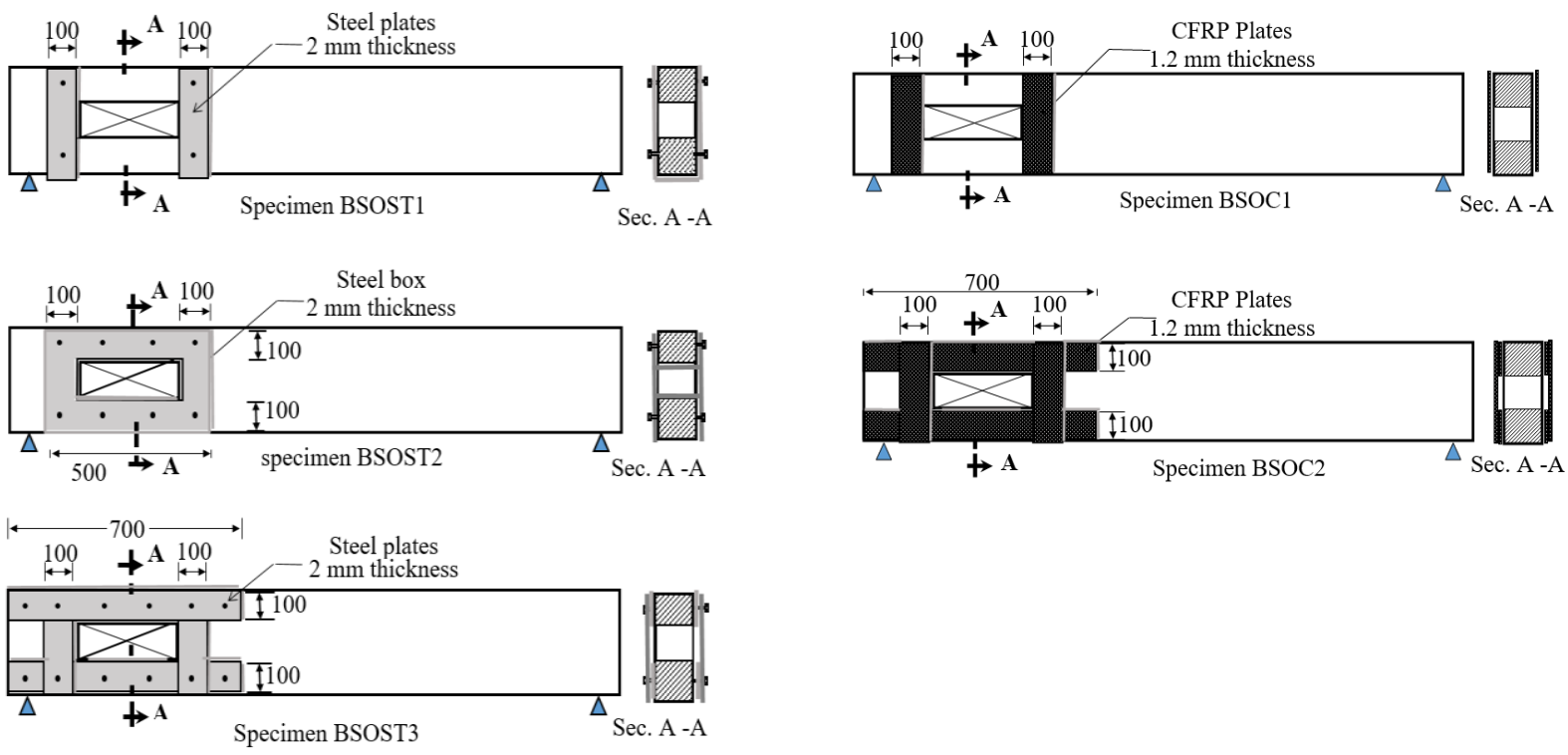

Fig. 4: Strengthening details of specimens in Group 2

(Diminsions in $\mathrm{mm}$ )

Six specimens were cast similar to reference beam CBMO with midspan opening. Three of them were strengthened using steel plates, $2 \mathrm{~mm}$ thick and 100 $\mathrm{mm}$ width and fixed by epoxy Sikadur®_31CF [18] and also with steel dowels $(5 \mathrm{~mm}$ diameter and 30 $\mathrm{mm}$ long) with different techniques. The other three specimens were strengthened using carbon fiber reinforced polymer CFRP Plates of $1.2 \mathrm{~mm}$ thickness and $100 \mathrm{~mm}$ width, Sika Carbodur®S1012 [18], fixed by epoxy Sikadur®-30LP. Figure 5 shows the dimensions of strengthening for specimens in Group 3; BMOST1, BMOST2, BMOST3, BMOC1, BSOC2 and BSOC3.
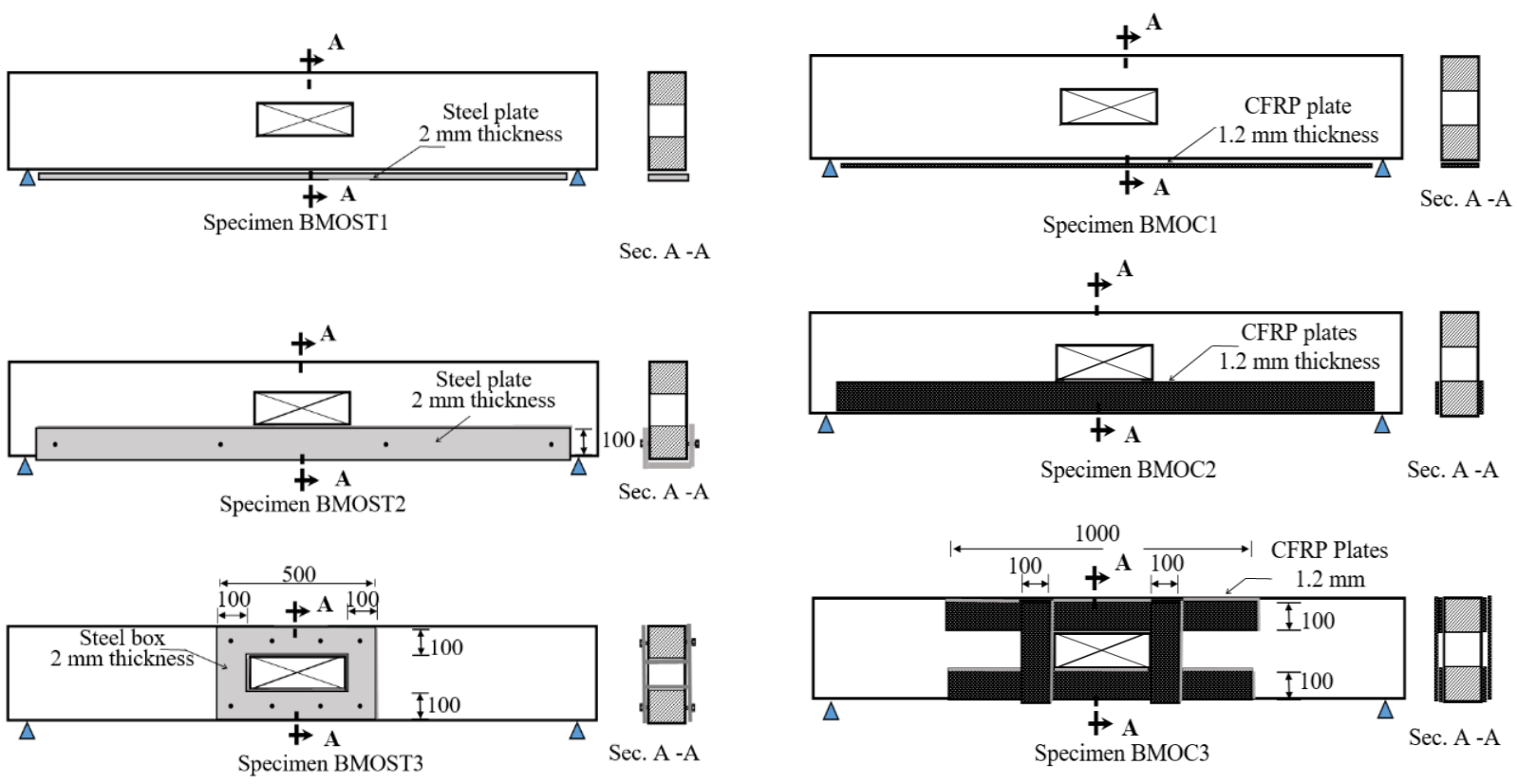

Fig. 5: Strengthening details of specimens in Group 3

(Diminsions in $\mathrm{mm}$ ) 
Table 1: Experimental test program

\begin{tabular}{|c|c|c|c|}
\hline Group & $\begin{array}{l}\text { Specimen } \\
\text { Code }\end{array}$ & $\begin{array}{l}\text { Location of } \\
\text { opening }\end{array}$ & Method of strengthening \\
\hline \multirow{3}{*}{1} & CB & $\begin{array}{l}\text { Without } \\
\text { opening }\end{array}$ & \multirow{3}{*}{ without strengthening } \\
\hline & CBSO & Side opening & \\
\hline & CBMO & $\begin{array}{l}\text { Midspan } \\
\text { opening }\end{array}$ & \\
\hline \multirow{5}{*}{2} & BSOST1 & Side opening & $\begin{array}{l}\text { Strengthened by vertical steel plates } 2 \mathrm{~mm} \text { thick in the form of } \mathrm{U} \\
\text { shape at the vertical edges of the opening. }\end{array}$ \\
\hline & BSOST2 & Side opening & $\begin{array}{l}\text { Strengthened by steel box formed from steel plates } 2 \mathrm{~mm} \text { thick as } \mathrm{U} \\
\text { shape around the opening. }\end{array}$ \\
\hline & BSOST3 & Side opening & $\begin{array}{l}\text { Strengthened by vertical and horizontal steel plates } 2 \mathrm{~mm} \text { thick } \\
\text { around the opening at both faces of the beam. }\end{array}$ \\
\hline & BSOC1 & Side opening & $\begin{array}{l}\text { Strengthened by vertical CFRP Plates } 1.2 \mathrm{~mm} \text { thick at the edges of } \\
\text { the opening at both faces of the beam. }\end{array}$ \\
\hline & BSOC2 & Side opening & $\begin{array}{l}\text { Vertical and horizontal CFRP Plates } 1.2 \mathrm{~mm} \text { thick around the } \\
\text { opening at both faces of the beam. }\end{array}$ \\
\hline \multirow{6}{*}{3} & BMOST1 & $\begin{array}{l}\text { Midspan } \\
\text { opening }\end{array}$ & $\begin{array}{l}\text { Strengthened by a steel plate } 2 \mathrm{~mm} \text { thick at the bottom surface of } \\
\text { the beam. }\end{array}$ \\
\hline & BMOST2 & $\begin{array}{l}\text { Midspan } \\
\text { opening }\end{array}$ & $\begin{array}{l}\text { Strengthened by } \mathrm{U} \text { steel plate } 2 \mathrm{~mm} \text { thick formed as } \mathrm{U} \text { shape at the } \\
\text { bottom side of the beam. }\end{array}$ \\
\hline & BMOST3 & $\begin{array}{l}\text { Midspan } \\
\text { opening }\end{array}$ & $\begin{array}{l}\text { Strengthened by steel box formed from steel plates } 2 \mathrm{~mm} \text { thick } \\
\text { around the interior and exterior edges of the opening. }\end{array}$ \\
\hline & BMOC1 & $\begin{array}{l}\text { Midspan } \\
\text { opening }\end{array}$ & $\begin{array}{l}\text { Strengthened by CFRP Plates } 1.2 \mathrm{~mm} \text { thick as horizontal strips at } \\
\text { the bottom side of the beam at both faces. }\end{array}$ \\
\hline & BMOC2 & $\begin{array}{l}\text { Midspan } \\
\text { opening }\end{array}$ & $\begin{array}{l}\text { Strengthened by CFRP Plates } 1.2 \mathrm{~mm} \text { thick at the bottom side of } \\
\text { the beam at both faces of the beam. }\end{array}$ \\
\hline & BMOC3 & $\begin{array}{l}\text { Midspan } \\
\text { opening }\end{array}$ & $\begin{array}{l}\text { Strengthened by vertical and horizontal CFRP Plates } 1.2 \mathrm{~mm} \text { thick } \\
\text { around the opening. }\end{array}$ \\
\hline
\end{tabular}

\section{Test Set-up and Instrumentation}

Specimens, $1900 \mathrm{~mm}$ span, were tested under fourpoint bending test by applying two equal concentrated loads at the two-thirds of the span. The loading system is shown in Fig. 6. Loads were applied in increments using a hydraulic jack of 50 ton maximum capacity. Deflections under the concentrated loads and at the midspan, first cracking loads and ultimate failure loads were recorded. Propagation of cracks was marked after each load increment up to failure. Three dial gauges of $0.01 \mathrm{~mm}$ accuracy and total capacity of $25 \mathrm{~mm}$ were used for measuring deflections. Figure 6 shows the arrangement of dial gages and the demic points for measuring the strain.

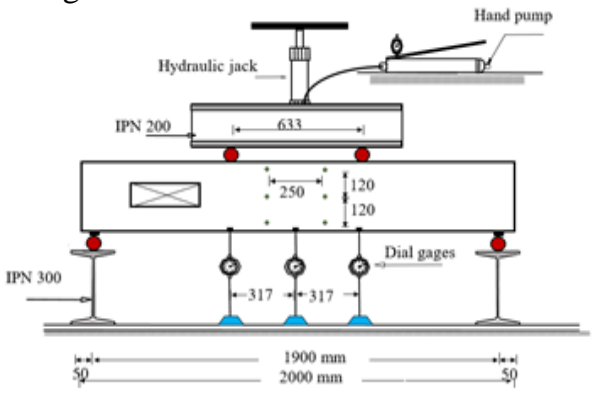

Fig. 6: Test set up and instrumentation 
Table 2 defines concrete mix proportions and compressive strength after 7 and 28 days.

Table 3 shows the mechanical properties of steel reinforcement and strengthening steel plates and

Table 2: Concrete mix proportions and compressive strength

\begin{tabular}{|c|c|c|c|c|c|c|c|c|c|c|}
\hline \multirow{2}{*}{$\begin{array}{l}\stackrel{0}{Z} \\
\stackrel{x}{z}\end{array}$} & \multicolumn{4}{|c|}{$\begin{array}{l}\text { Mix proportions } \\
\mathrm{kg} / \mathrm{m}^{3}\end{array}$} & \multirow{2}{*}{ 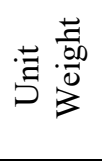 } & \multirow{2}{*}{ 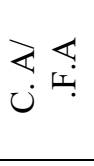 } & \multirow{2}{*}{$\frac{0}{j^{\circ}}$} & \multirow{2}{*}{$\underset{\Xi}{\stackrel{\Xi}{\Xi}}$} & \multicolumn{2}{|c|}{$\begin{array}{c}\text { Compressive Strength } \\
\mathrm{N} / \mathrm{mm}^{2}(\mathrm{MPa})\end{array}$} \\
\hline & $\mathrm{C}$ & W & F.A & C.A & & & & & $\begin{array}{l}\text { 7days } \\
\mathrm{MPa} \\
\end{array}$ & $\begin{array}{c}28 \text { days } \\
\mathrm{MPa}\end{array}$ \\
\hline 1 & 350 & 158 & 640 & 1280 & 2440 & 2 & 45 & 31 & 23.0 & 30.73 \\
\hline
\end{tabular}

Where: $\mathrm{C}=$ Portland cement from Suez Company

$$
\mathrm{W}=\mathrm{Water}
$$

F. A. = Fine aggregate

C. A. = Coarse aggregate (crushed dolomite with a nominal max. size of $25 \mathrm{~mm}$ )

Table 3: Mechanical properties of steel reinforcement and strengthening plates

\begin{tabular}{lllll}
\hline Steel Type & $\begin{array}{l}\text { Yield Stress } \\
(\mathrm{MPa})\end{array}$ & $\begin{array}{l}\text { Tensile Strength } \\
(\mathrm{MPa})\end{array}$ & Elongation $\%$ & $\begin{array}{l}\text { Modulus of Elasticity } \\
(\mathrm{MPa})\end{array}$ \\
\hline High Tensile & 360 & 520 & 15.0 & 205940 \\
\hline Mild Steel & 248 & 366 & 22 & 198094 \\
\hline Steel Plates & 221 & 235 & 24 & 205940 \\
\hline
\end{tabular}

Table 4: Mechanical properties of CFRP Plates [18]

\begin{tabular}{lc}
\hline Property & CFRP \\
Thickness, $\mathrm{mm}$ & Sika carbodur ${ }^{\mathrm{S}} \mathrm{S} 1012$ \\
\hline Plate width, $\mathrm{mm}$ & 1.2 \\
\hline Density, g/cm ${ }^{3}$ & 100 \\
\hline Tensile E-Modulus, $\mathrm{MPa}$ & 1.6 \\
\hline Tensile strength, $\mathrm{MPa}$ & 165000 \\
\hline Strain at break & Min. value $=2800$ \\
\hline
\end{tabular}

\section{Experimental Results}

\subsection{Crack Patterns}

Figure 7 shows the crack pattern for reference specimens CB, CBSO and CBMO in Group 1. For the control specimen without opening, $\mathrm{CB}$, cracks started at load $35 \mathrm{kN}$ from the midspan of the beam at the tension side (bottom face) and directed upward in a vertical direction. With increasing load cracks spread in the middle third of the span. Before the failure, cracks directed with an inclined angle of about $45^{\circ}$ form the bottom surface toward the points of loading as shown in Fig. 7a.

The first cracking load for the beam with side opening, CBSO, starts at $20 \mathrm{kN}$ from the support near the opening and directed to the nearest corner of the opening then directed to the adjacent loading point at the top surface of the beam. At cracking load, cracks started also at midspan. With increasing load cracks propagated in the middle third of the span from the tension side to upward as shown in Fig. $7 \mathrm{~b}$.
Table 4 identifies the mechanical properties of CFRP Plates [18]. 


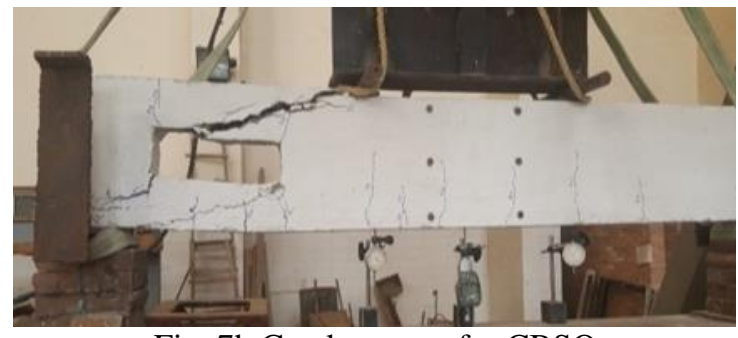

Fig. 7b Crack pattern for CBSO

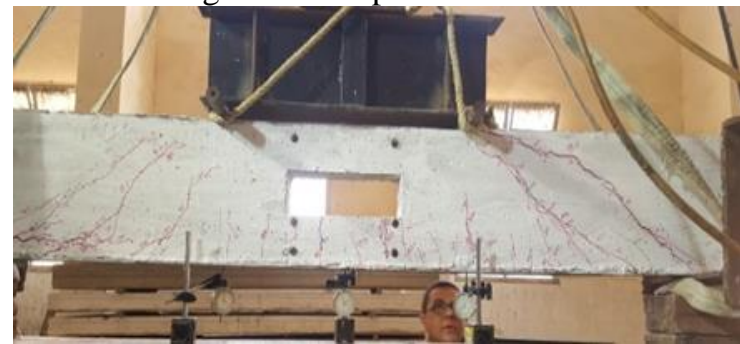

Fig. 7c Crack pattern for CBMO

Fig. 7: Crack patterns for specimens in Group 1

Figure 8 shows the crack patterns for strengthened specimens with side openings in Group 2; BSOST1, BSOST2, BSOST3, BSOC1and BSOC2. Cracks started to propagate at loads $20,25,25,20$ and $25 \mathrm{kN}$ for beams BSOST1, BSOST2, BSOST3, BSOC1and BSOC2 respectively. The different methods of strengthening for BSOST1 and BSOC1 were not effective for increasing the cracking loads in case of the side opening; this may be attributed to the propagation of cracks at the midspan of specimens.

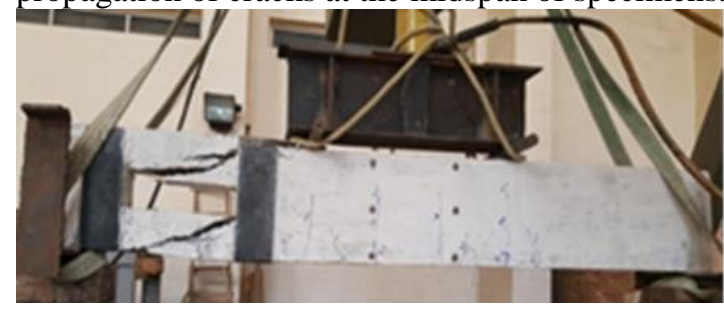

Fig. 8a Crack pattern for BSOST1

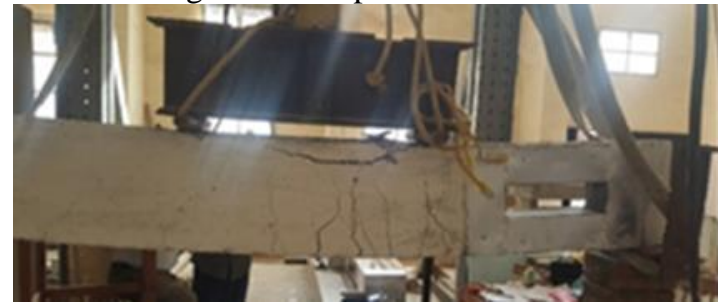

Fig. 8b Crack pattern for BSOST2

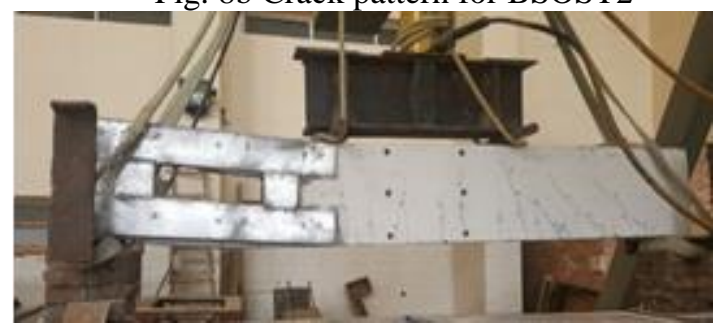

Fig. 8c Crack pattern for BSOST3

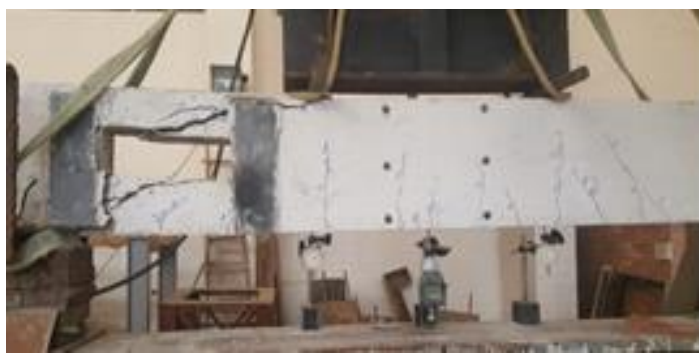

Fig. 8d Crack pattern for BSOC1

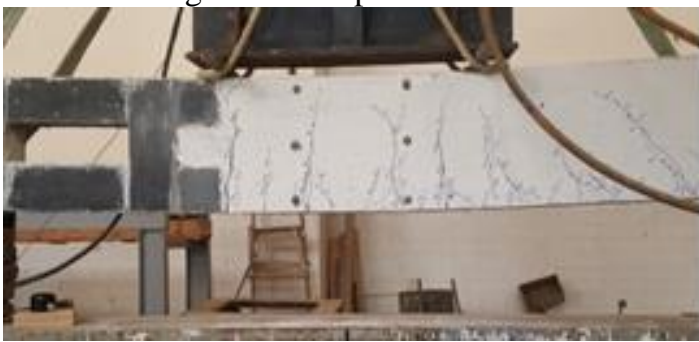

Fig. 8e Crack pattern for BSOC2

Fig. 8: Crack patterns for specimens in Group 2

Figure 9 shows the crack patterns for strengthened specimens with midspan openings in Group 3; BMOST1, BMOST2, BMOST3, BMOC1, and BMOC2 and BMOC3. Cracks started to propagate at loads $45,50,25,50,50$ and $40 \mathrm{kN}$ for beams BMOST1, BMOST2, BMOST3, BMOC1, and BMOC2 and BMOC3 respectively. The different methods of strengthening by using CFRP Plates were effective for increasing the cracking loads in case of midspan opening.

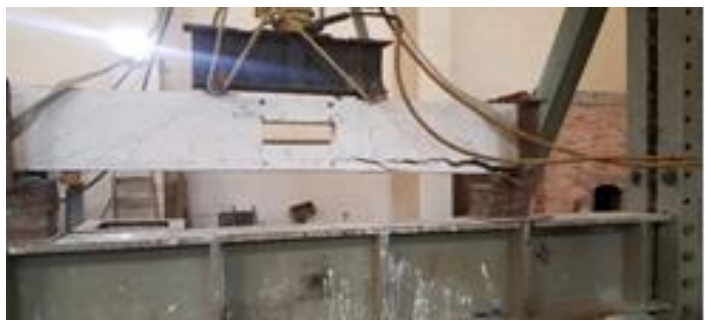

Fig. 9a Crack pattern for BMOST1

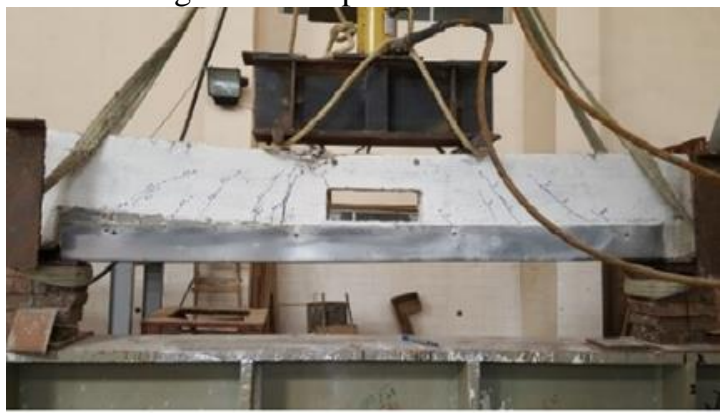

Fig. 9b Crack pattern for BMOST2 


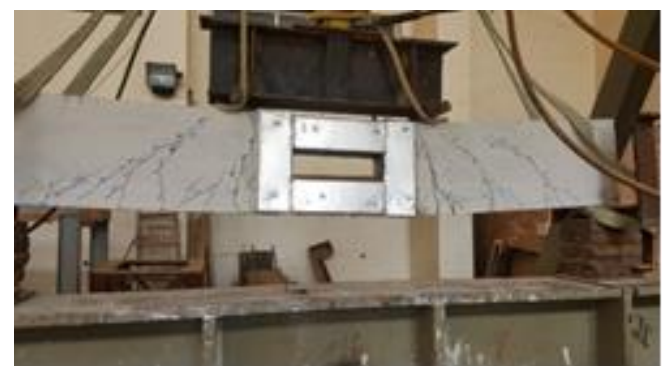

Fig. 9c Crack pattern for BMOST3

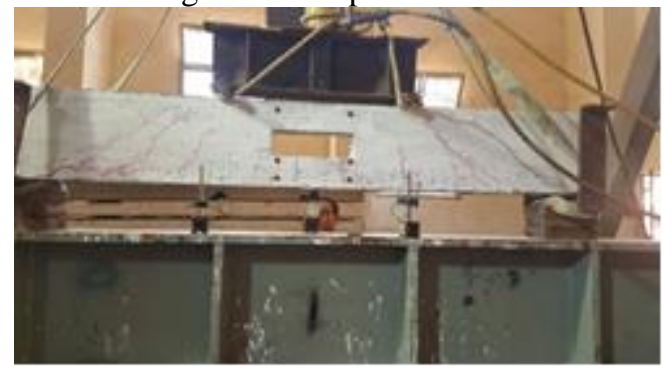

Fig. 9d Crack pattern for BMOC1

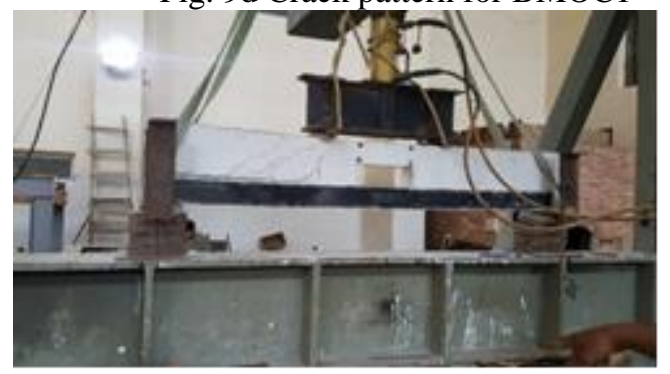

Fig. 9e Crack pattern for BMOC2

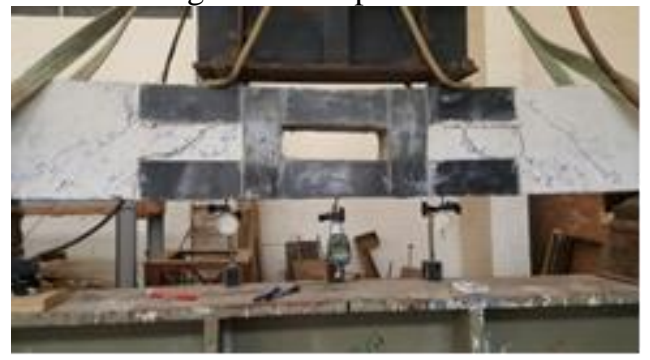

Fig. 9f Crack pattern for BMOC3

Fig. 9: Crack patterns for specimens in Group 3

\subsection{Cracking and ultimate failure load}

First cracks for beams CB, CBSO and CBMO were recorded at load 35,20 and $25 \mathrm{kN}$ respectively. It is noticed that the side opening decreased the cracking load by about $43 \%$ while the midspan opening decreased it by about $29 \%$.

Ultimate failure loads for $\mathrm{CB}, \mathrm{CBSO}$ and $\mathrm{CBMO}$ were recorded at load 120,40 and $90 \mathrm{kN}$ respectively. It is noticed that the side opening decreased the ultimate failure load by about $67 \%$ while the midspan opening decreased it by about $25 \%$.

Ultimate failure loads for specimens BSOST1, BSOST2, BSOST3, BSOC1and BSOC2 were recorded at load 50, 80, 85, 50 and $115 \mathrm{kN}$ respectively. It is noticed that the second method of strengthening for BSOC2 using horizontal and vertical CFRP Plates around the opening from both faces of the beam gave best results.

This technique increased the ultimate failure with respect to the corresponding specimen CBSO by about $188 \%$, which approached to the ultimate failure of control beam without opening CB.

Ultimate failure loads for specimens BMOST1, BMOST2, BMOST3, BMOC1, and BMOC2 and BMOC3 in Group 3 were recorded at loads 100, 120, $95,145,135$ and $130 \mathrm{kN}$ respectively. All methods of strengthening were very effective in case of midspan opening. The ultimate loads for specimens BMOST1, BMOST2, BMOST3, BMOC1, and BMOC2 and BMOC3 were increased more than the corresponding control beam CBMO by about 11\%, 33\%, 6\%, 61\%, $50 \%$ and $44 \%$. Using CFRP Plates gave better result than using steel plates. The ultimate failure loads were increased in case of using CFRP Plates than the control beam without opening CB. It is noticed that for specimen BMOC1, using CFRP Plates at the bottom face of the beam at the overall span length gave the best result in this group.

Figure 10 compares ultimate loads of all tested strengthened beams with respect to their reference beams.

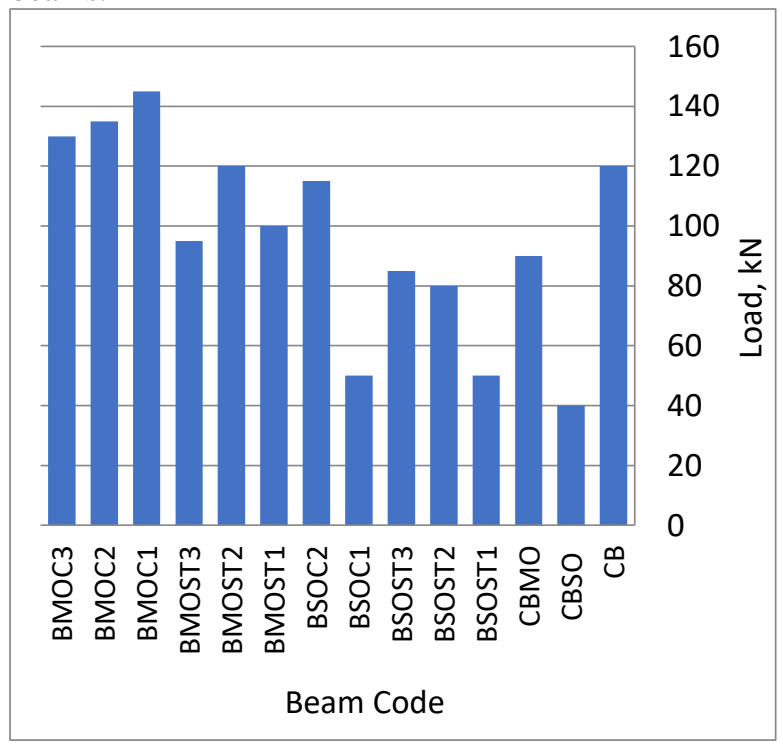

Fig. 10: Ultimate loads of all tested beams

\subsection{Deflection}

Ductility of beams can be defined as the ratio between the maximum deflection due to the ultimate load and the maximum deflection at the first cracking load. Energy absorption is always defined as the area under the load-deflection curve until failure.

Figure 11 compares the load-deflection curves for reference reinforced concrete beams in Group 1. The 
figure shows the reduction of the stiffness as well as the reduction in energy absorption due to openings. The reduction of the strength was affected by the opening locations. It can be seen that the side opening reduces the strength more than the midspan opening with respect to the control beam without opening as shown in Fig. 11.

Figure 12 shows the load-deflection curves for reinforced concrete beams strengthened by steel plates by the different techniques in Group 2. Figure 13 shows the load-deflection curves for reinforced concrete beams strengthened by CFRP plates in Group 2

Figure 14 shows the load-deflection curves for reinforced concrete beams strengthened by steel plates in Group 3. Figure 15 shows the load-deflection curves for reinforced concrete beams strengthened by CFRP plates by the different techniques.

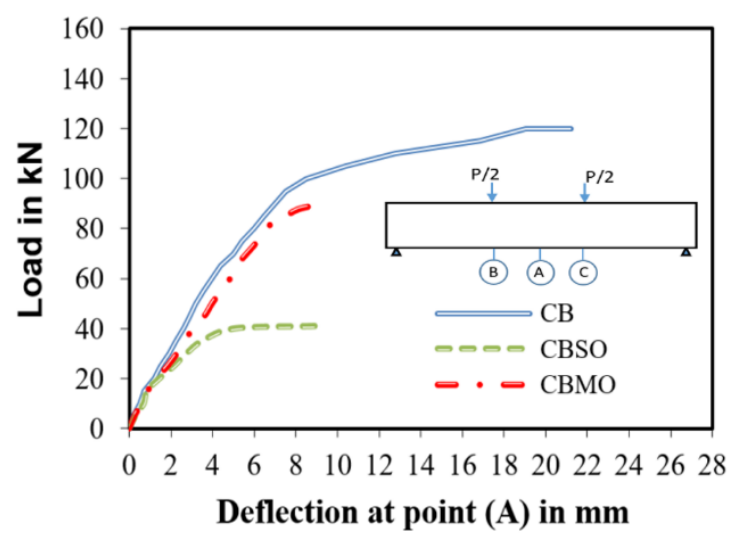

Fig. 11: Load deflection curves for reference specimens in Group 1.

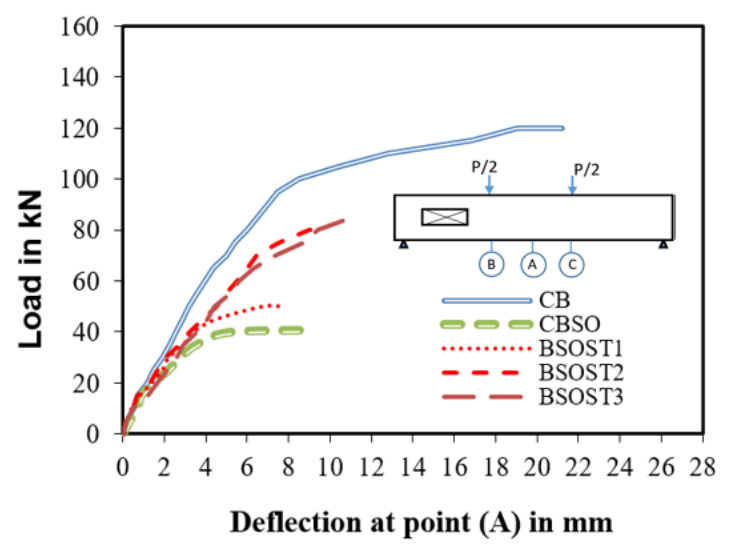

Fig. 12: Load deflection curves for specimens strengthened by steel plates in Group 2.

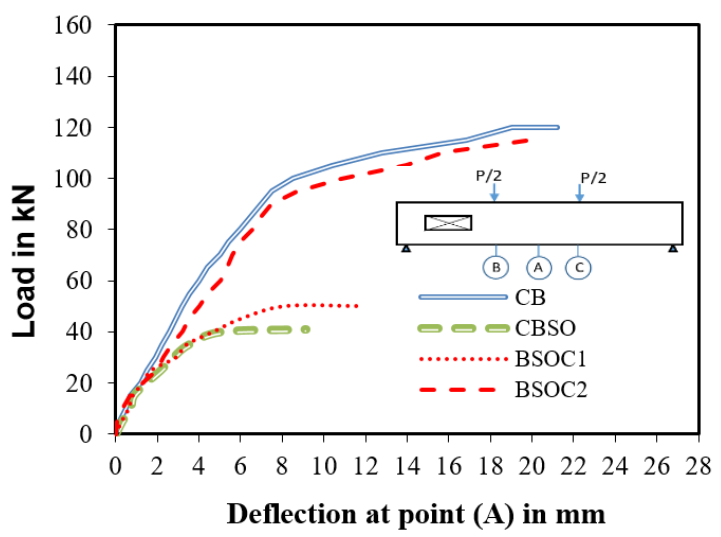

Fig. 13: Load deflection curves for specimens strengthened by CFRP plates in Group 2.

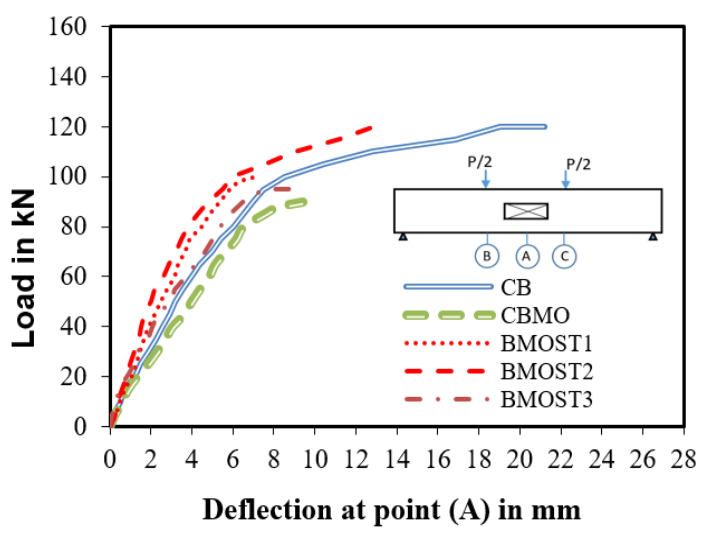

Fig. 14: Load deflection curves for specimens strengthened by steel plates in Group 3.

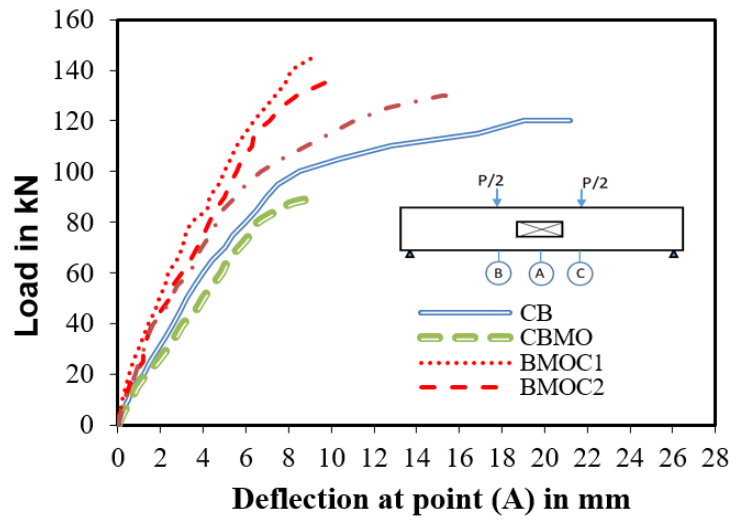

Fig. 15: Load deflection curves for specimens strengthened by CFRP plates in Group 3.

\section{Conclusions}

Based on the test results, the following conclusions can be obtained: 


\section{Mohamed A. Kandil, Gaylan M. Saad and Nageh N. MELEKA " Flexural and Shear Strengthening of RC Beams with Large Openings by Steel or CFRP Plates"}

Large side opening in beam depth decreases the stiffness as well as the strength of the beam more than the midspan opening.

All strengthened techniques applied in this research improved the results of the strength, ductility, and energy absorption with the corresponding reference specimens.

First cracking loads for reference specimens CBSO and CBMO decreased by about $43 \%$ and $29 \%$ with respect to, the control beam without opening $\mathrm{CB}$.

Ultimate failure loads for reference specimens CBSO and CBMO decreased by about $67 \%$ and $25 \%$ compared to, the beam without opening $\mathrm{CB}$.

The method of strengthening for BSOC2 using horizontal and vertical CFRP plates around the opening from both faces of the beam gave best results. This technique increased the ultimate failure with respect to, the corresponding specimen CBSO by about $188 \%$, which approached to the failure load of the control beam CB.

The ultimate loads for specimens in Group 3; BMOST1, BMOST2, BMOST3, BMOC1, and $\mathrm{BMOC} 2$ and $\mathrm{BMOC} 3$ were increased more than the corresponding control beam CBMO by about $11 \%$, $33 \%, 6 \%, 61 \%, 50 \%$ and $44 \%$.

The ultimate failure loads increased in the case of using CFRP Plates more than the ultimate failure load of the control beam $\mathrm{CB}$. It is noticed that for specimen BMOC1, using CFRP Plates at the bottom face of the beam at the overall span length gave the best result in case of midspan opening.

Using CFRP Plates gave a better result than using steel plates for strengthening reinforced concrete beams with midspan openings.

\section{References}

[1] Abdul-Razzaq Kh.S ., and Abdulkareem, M.M., " Behavior of RC T-Beams with Openings Literature Review", The Second Conference of Post Graduate Researches, College of Engineering, Al-Nahrain Univ., Baghdad, Iraq 4th Oct. 2017.

[2] Jithinbose K.J., Thomas J. and Parappattu, N.B., " Effect of Openings in Beams - A Review ", International Journal of Innovative Research in Advanced Engineering (IJIRAE) ISSN: 23492763 Issue 09, Volume 3 (September 2016).

[3] Rezwana B.H., Shaibal, A., Saikat B. and Sharmin R.C., " Effects of Opening on the Behavior of Reinforced Concrete Beam ", IOSR Journal of Mechanical and Civil Engineering (IOSR-JMCE)e-ISSN: 2278-1684,p-ISSN: 2320334X, Volume 11, Issue 2 Ver. VII (Mar- Apr. 2014), PP 52-61
[4] Mansur, M.A. and Kiang, H.t., "Concrete beams with openings: analysis and design", CRC Press, London, 1999.

[5] Egyptian Code of Practice ECP 2032018), "Egyptian Code for Design and Construction of Reinforced Concrete Structures", Ministry of Housing, Utilities and Urban Development, Housing and Building National Research Center HBNRC, Cairo, Egypt, 2018.

[6] British Standard (BS 8110-1997), "Code of Practice for Reinforced Concrete", British Standard Institution, 1997.

[7] ACI Committee 318, "Building Code Requirements for Reinforced Concrete", ACI318R-19, American Concrete Institute, 2019.

[8] Meleka, N.N., Kamal, M.M., Soliman, M.Hand Emam, A.A., "Strengthening of Beams with Large Web Openings in Shear Spans by Using Glass and Steel Fibrous Concrete", Fourth Conference of Egyptian Rural Development, Menoufia University, 16 September 2003, p.p. 1407- 1430.

[9] Meleka, N.N., Heiza, K.M,.., and Elwakad, N.Y., "Shear Strengthening of Self-Consolidating Reinforced Concrete Deep Beam with a Central Opening", Ain Shams Journal of Civil Engineering, ASJCE, Vol. March, 2009.

[10] Mirza, M. S; and McCutcheon, J. 0., "Behavior of Reinforced Concrete Beams under Combined Bending, Shear, and Torsion", ACI Journal, Proceedings V. 66, No. 5, .May 1969, pp. 421427.

[11] Nabil A., Meleka N.N., Hieza Kh., Tayel M.A, " State-of the-Art Review: Strengthening of Reinforced Concrete Structures - Different Strengthening Techniques", Sixth International Conference on Nano-Technology in Construction NTC, Cairo, Egypt, 22-24 March 2014.

[12] Chalioris, C.E., "Tests and Analysis of Reinforced Concrete Beams under Torsion Retrofitted with FRP Strips", Proceedings 13th Computational Methods and Experimental Measurements (CMEM), Prague, Czech Republic, 2007.

[13] Ameli, M. and Ronagh, H.R., "Behavior of FRP Strengthened Reinforced Concrete Beams under Torsion", Journal of Composites for Construction, No.11 (2), 2007, PP.192- 200.

[14] Soluit, A.K, Motawea, A.M. Elsayed K.M. and Shalaby, S.H. "Torsional Behavior of RC Beams Strengthened with Fiber Reinforced Polymer Sheets", Engineering Research Journal

[15] Meleka, N.N., Tayel, M.A. and Ramadan, A.M., "Experimental Evaluation of Advanced Techniques for Repair and Strengthening of 
Mohamed A. Kandil, Gaylan M. Saad and Nageh N. MELEKA " Flexural and Shear Strengthening of RC Beams with Large Openings by Steel or CFRP Plates"

Reinforced Concrete Slabs", Alexandria Engineering Journal, Vol. 43, No. 3, May 2004.

[16] Meleka N.N., Safan M.A., Bashandy A.A., AbdElrazek A.S., " Rehabilitation of Elliptical Parabolic Reinforced Concrete Shells with Openings", ASIAN Journal of Civil Engineering (BHRC) Vol. 14, No. 6, pp.945-963, June 2013.

[17] Meleka N.N., Hieza Kh., Tayel M.A, Nabil A., " Strengthening of Axially Loaded Circular Concrete Columns Using Externally Bonded GFRP Lateral Confinement and Near Surface Mounted Technique", Sixth International Conference on Nano-Technology in Construction NTC, Cairo, Egypt, 22-24 March 2014.

[18] Sika Egypt for Construction Chemicals S.A.E. International, http://www.Sika.com. 